Review

\title{
A Review of Hydrogen as a Fuel in Internal Combustion Engines
}

\author{
Behdad Shadidi ${ }^{1, *(1)}$, Gholamhassan Najafi ${ }^{2}$ and Talal Yusaf ${ }^{3}(\mathbb{C}$ \\ 1 Biosystem Engineering, Bu-Ali Sina University, Hamedan 6517838695, Iran \\ 2 Department of Biosystem Engineering, Faculty of Agriculture, Tarbiat Modares University, \\ Tehran 1497713111, Iran; g.najafi@modares.ac.ir \\ 3 School of Engineering and Technology, Central Queensland University, Queensland, QLD 4009, Australia; \\ t.yusaf@cqu.edu.au \\ * Correspondence: b.shadidi@basu.ac.ir; Tel.: +98-8138381601
}

\section{check for}

updates

Citation: Shadidi, B.; Najafi, G.; Yusaf, T. A Review of Hydrogen as a Fuel in Internal Combustion Engines. Energies 2021, 14, 6209. https:// doi.org/10.3390/en14196209

Academic Editor: Adam Revesz

Received: 27 August 2021

Accepted: 26 September 2021

Published: 29 September 2021

Publisher's Note: MDPI stays neutral with regard to jurisdictional claims in published maps and institutional affiliations.

Copyright: (c) 2021 by the authors. Licensee MDPI, Basel, Switzerland. This article is an open access article distributed under the terms and conditions of the Creative Commons Attribution (CC BY) license (https:// creativecommons.org/licenses/by/ $4.0 /)$.

\begin{abstract}
The demand for fossil fuels is increasing because of globalization and rising energy demands. As a result, many nations are exploring alternative energy sources, and hydrogen is an efficient and practical alternative fuel. In the transportation industry, the development of hydrogen-powered cars aims to maximize fuel efficiency and significantly reduce exhaust gas emission and concentration. The impact of using hydrogen as a supplementary fuel for spark ignition (SI) and compression ignition (CI) engines on engine performance and gas emissions was investigated in this study. By adding hydrogen as a fuel in internal combustion engines, the torque, power, and brake thermal efficiency of the engines decrease, while their brake-specific fuel consumption increase. This study suggests that using hydrogen will reduce the emissions of $\mathrm{CO}, \mathrm{UHC}, \mathrm{CO}_{2}$, and soot; however, $\mathrm{NO}_{\mathrm{x}}$ emission is expected to increase. Due to the reduction of environmental pollutants for most engines and the related environmental benefits, hydrogen fuel is a clean and sustainable energy source, and its use should be expanded.
\end{abstract}

Keywords: hydrogen fuel; renewable energy

\section{Introduction}

The rise in the world population and the excessive use of fossil fuels have resulted in a significant increase in the global demand for energy production in the twenty-first century [1]. Total global oil consumption was 3928 million tons in 2008 and is expected to reach 5300 million tons by 2021 [2,3]. However, oil is a finite resource that is becoming increasingly scarce and expensive [4]. Because of their availability, fossil fuels now meet around $65 \%$ of the world's energy demand [5]. Transportation vehicles and machinery that require fossil fuels to operate use a significant proportion of this energy. In 2018, 1.42 billion automobiles and light trucks were on the road globally [6]. By 2050, the number of automobiles is anticipated to exceed 2 billion [7].

The decline in fossil fuels availability has led to an energy (fuel) crisis. IC engines, on the other hand, will continue to dominate the transportation and power industries due to their flexibility. Pollutants emitted by internal combustion engines affect the atmospheric conditions and cause serious problems such as global warming, air pollution, acidic rains, and respiratory problems [8]. So far, many researchers have tried to create a suitable combustion system for the complete combustion of hydrocarbons $[9,10]$. However, the issue is still challenging. Increasing fuel quality and creating better fuel combustion in engines are among the methods that have been considered to solve this problem. In these methods, there is no need to make changes in the engine structure. The use of biofuels, water, nanoparticles, and other additives is among the solutions that have been studied to increase combustion and fuel quality [8]. To ensure the long-term safety and viability of IC engines, "clean-burning" fuels derived from renewable sources must be developed as soon as feasible [11]. In this respect, research and investments in the use of renewable 
and sustainable alternative fuels, as well as improvement of engine energy efficiency, have been made [12-15].

One of the most promising possibilities for meeting future energy demands is hydrogen [16]. Hydrogen is environmentally friendly when it is produced from renewable sources in a sustainable and efficient process [17]. In comparison to hydrocarbon fuels such as natural gas, gasoline, and diesel, utilizing hydrogen as a fuel in internal combustion engines can improve thermal efficiency while decreasing carbon emissions. A key benefit of using hydrogen for transportation is that it increases our reliance on renewable sources while reducing our usage of non-renewable fossil fuels [18].

Hydrogen has remarkable qualities as a carbon-free fuel. Hydrogen has three times the heating value of petroleum in internal combustion engines and fuel cells and produces considerably fewer hazardous tailpipe emissions, which is one of the major disadvantages of fossil fuels [19]. One of the major advantages of hydrogen is that it is an environmentally friendly fuel since when utilized in a fuel cell, it produces solely $\mathrm{H}_{2} \mathrm{O}$ [20]. Hydrogen has a heating value 4,2.8, and 2.4 times higher than those of coal, gasoline, and methane, respectively [21]. When compared to fossil fuels, hydrogen, the most abundant element, has the highest specific energy content [22].

Compression ignition (CI) diesel engines are widely used in heavy transport, power generation, and agricultural applications. Some of their benefits include increased torque, increased power, increased thermal efficiency, and lower fuel consumption $[23,24]$. Unfortunately, diesel engines create more nitrogen oxides $\left(\mathrm{NO}_{\mathrm{x}}\right)$, unburned hydrocarbons (UHC), carbon monoxide (CO), and soot [25]. Despite the fact that heavy-duty engines emit pollutants into the environment, they are unlikely to be phased out anytime soon, as alternatives such as large-scale fuel cell manufacturing remain difficult and expensive [26]. Hydrogen fuel in $\mathrm{CI}$ engines can minimize $\mathrm{CO}_{2}$ emissions while preserving or even enhancing engine performance $[27,28]$.

Because of its unique properties, hydrogen is more suited for use in spark ignition (SI) engines than in compression combustion (CI) engines $[29,30]$. The adiabatic flame rate of hydrogen, for example, is much higher than that of gasoline, which enhances the combustion stability [30,31]. Furthermore, hydrogen has a significantly greater diffusion coefficient than gasoline, resulting in a more homogeneous combination of air and fuel. When added, hydrogen's broad flammability makes it easier to run engines in lean circumstances [32]. In addition, because hydrogen has a higher combustion temperature (about $858 \mathrm{~K}$ [33]), it is better suited to SI engines than to compression combustion (CI) engines [34-36].

Several studies on the use of hydrogen in spark ignition engines have been done $[37,38]$ that confront problems such as low volumetric efficiency and decreased power density. Table 1 [39] compares the characteristics of hydrogen, gasoline, and diesel.

Table 1. Hydrogen, gasoline, and diesel have different characteristics.

\begin{tabular}{cccc}
\hline Properties & Hydrogen & Gasoline & Diesel \\
\hline Carbohydrate content (mass percent) & 0 & 84 & 86 \\
Molecular mass & 2.015 & 110 & 170 \\
A/F stoichiometric ratio & 34.3 & 14.6 & 17 \\
Temperature of ignition (K) & 858 & 530 & - \\
Temperature of adiabatic flame $(\mathrm{K})$ & 2384 & 2270 & 2300 \\
293 K (cm/s) flame speed & 237 & 41.5 & - \\
Flammability limits (vol percent in air) & $4.1-75$ & $1.5-7.6$ & $0.6-5.5$ \\
Quenching the gap $(\mathrm{cm})$ & 0.06 & 0.2 & - \\
Lower heating value per kilogram $(\mathrm{MJ} / \mathrm{kg})$ & 120 & 44 & - \\
Diffusion coefficient $\left(\mathrm{cm}^{2} / \mathrm{s}\right)$ under stoichiometric conditions & 0.61 & 0.05 & - \\
\hline
\end{tabular}

To employ pure hydrogen in engines, major engine modifications are necessary. Instead, hydrogen may be utilized as an auxiliary fuel in automobiles to minimize fuel consumption and emissions, as a middle solution $[40,41]$. 
Given the importance of hydrogen fuels as renewable and clean fuels in internal combustion engines, it is important to examine their influence on spark and compression ignition engines. The goal of this research is to look at how hydrogen fuels affect the performance and emissions of spark and compression ignition engines.

\section{Production Methods of Hydrogen}

Hydrogen has become one of the most useful alternatives to fossil fuels today due to its properties such as great range of flammability, minor quenching distance, minimal ignition source energy, great diffusivity, and low density [42]. Since hydrogen is one of the many elements in the environment, it is easily available [43].

Hydrogen is not available in its pure form in nature (atmosphere). However, it can be produced from hydrogen-containing compounds such as fossil fuels, hydrogen sulfide, biomass, and water. To acquire hydrogen, it must first be separated from the other elements in the combination [42].

The following are ways for producing hydrogen. Due to their lower cost (less than $2 \$ / \mathrm{kg} \mathrm{H}_{2}$ ) compared to other methods, steam methane reforming and coal gasification are the current industrially established processes for hydrogen production [17].

\subsection{Steam Methane Reforming}

Over $90 \%$ of the world's hydrogen is produced using the steam methane reforming process [44]. Under a 3-25 bar pressure (1 bar $=14.5$ psi) in the presence of a catalyst, methane combines with steam to form hydrogen, carbon monoxide, and a trace amount of carbon dioxide. Methane steam reforming is an endothermic reaction, which means it requires heat to complete the process [45]. Most of the hydrogen generated in the world today is derived from natural gas.

The process of steam-methane reforming for hydrogen production is similar to that of producing other fuels like ethanol, propane, or even gasoline. The first stage is to generate carbon monoxide and steam, which are then combined with a catalyst to produce more hydrogen. In a final production stage known as "pressure swing adsorption", carbon dioxide and other impurities are removed from the gas stream, leaving essentially pure hydrogen [45].

Reaction of steam-methane reforming [45]:

$$
\text { Heat }+\mathrm{H}_{2} \mathrm{O}+\mathrm{CH}_{4}+\rightarrow \mathrm{CO}+3 \mathrm{H}_{2}
$$

Reaction between water and gas [45]:

$$
\mathrm{H}_{2} \mathrm{O}+\mathrm{CO} \rightarrow \text { Heat (few amount) }+\mathrm{H}_{2}+\mathrm{CO}_{2}
$$

\subsection{Electrolysis}

Electrolysis is a viable method for generating carbon-free hydrogen from renewable and nuclear energy. The process of splitting water into hydrogen and oxygen using electricity is known as hydrogen generation. An electrolyte separates to the anode and the cathode in an electrolyzer. Because of the varied types of electrolyte material and ionic species they conducts, different electrolyzers work in different ways [46].

Recently, research has been done on hydrogen wind systems based on the electrolysis of water with wind energy to generate the electricity required by this method using a renewable wind source. In this regard, sources including wind energy are used as a renewable energy option. Using this technology, renewable energy-based electricity can be converted to hydrogen, a carbon-free energy carrier that does not emit greenhouse gas $[47,48]$.

\subsection{Coal Gasification}

Coal is made up of two parts: carbon-based matter (the decomposed remnants of prehistoric plants) and mineral stuff (which comes from the ground from which the coal 
is dug). Carbon-based matter is made up of five primary components: carbon, hydrogen, oxygen, nitrogen, and sulfur [49].

To comprehend gasification, we must first comprehend combustion. The full oxidation of a fuel such as coal, which generates heat and carbon dioxide, is known as combustion. Carbon dioxide is a non-combustible end product of the burning process because it cannot be further oxidized. However, coal is not fully oxidized during gasification. Coal is instead treated with a substance known as a gasification agent. Gasification is endothermic, meaning it produces no heat. In reality, it requires heat input in order to proceed. Because the resultant gas is not completely oxidized, it can be burnt as a fuel.

The method of producing hydrogen from coal begins with partial oxidation, which involves adding some air to the coal, which produces carbon dioxide through traditional burning. However, not enough heat is provided to totally burn the coal-simply enough to heat the gasification reaction. The partial oxidation process also produces carbon dioxide, which is used as a gasifier. Carbon monoxide is formed when carbon dioxide interacts with the remainder of the carbon in coal (this is an endothermic gasification reaction, which needs heat input). There is no hydrogen yet. Carbon monoxide in the gas stream now reacts with steam to produce hydrogen and carbon dioxide; therefore, we are now producing hydrogen (Figure 1).

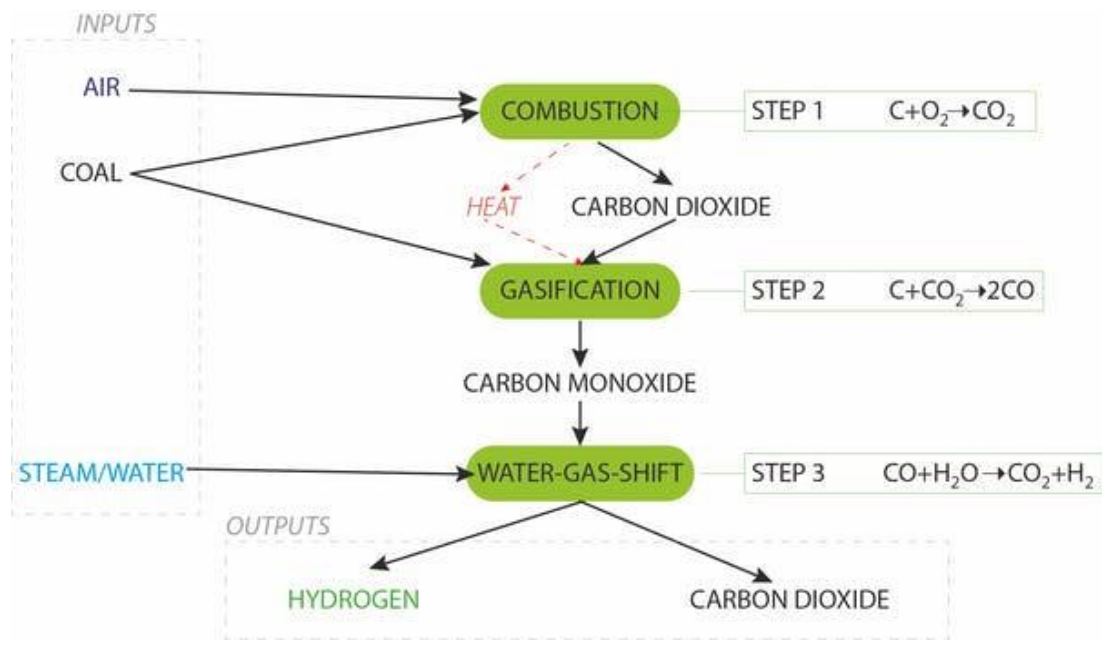

Figure 1. Coal-based hydrogen production [49].

\subsection{Biomass Gasification}

Gasification is a process that transforms organic or fossil-based carbonaceous materials into carbon monoxide, hydrogen, and carbon dioxide at high temperatures without combustion. Biomass does not gasify as quickly as coal because it creates additional hydrocarbon compounds in the gas mixture entering the gasifier, especially when no oxygen is employed. As a result, an additional step to reform these hydrocarbons using a catalyst to produce a clean syngas is usually required. An example of a simplified reaction is [50]:

$$
\mathrm{H}_{2} \mathrm{O}+\mathrm{O}_{2}+\mathrm{C}_{6} \mathrm{H}_{12} \mathrm{O}_{6} \rightarrow \mathrm{H}_{2}+\mathrm{CO}_{2}+\mathrm{CO}+\text { other species }
$$

Note that glucose is used as a cellulose substitute in the aforementioned process. The content and complexity of the actual biomass varies greatly, with cellulose being one of the most important components [51].

Supercritical water gasification is a promising hydrothermal technology for transforming waste biomass to hydrogen-rich syngas (gaseous, liquid, and solid bio-products) and bio-oil at high temperatures and elevated pressures [52]. Water in this process exists in its supercritical condition $\left(\mathrm{T}>374{ }^{\circ} \mathrm{C}, p>22.1 \mathrm{MPa}\right)$. Supercritical water conditions near the critical point are mostly recommended; water can easily hydrolyze natural polymers of biomass such as cellulose, hemicellulose, and lignin [53]. 


\subsection{Microbial Biomass Conversion}

Microbial biomass conversion methods make use of microorganisms' capacity to consume and digest biomass while also releasing hydrogen. This study might lead to commercial-scale systems in the mid- to long-term, depending on the path taken.

Refined sugars, raw biomass sources like maize stover, and even wastewater can be used as organic matter. These methods are frequently referred to as "dark fermentation" approaches since they do not need the use of light [54].

Microbes generate hydrogen directly in direct hydrogen fermentation. These bacteria can break down complex compounds in a variety of ways, and enzymes may combine the byproducts from some of these routes to create hydrogen [54].

Microbial electrolysis cells (MECs) are devices that generate hydrogen by combining the energy and protons supplied by microorganisms breaking down organic materials with a modest electric current. This technology is still in its early stages, and researchers are striving to improve several elements of it, including searching for lower-cost materials and determining the best microorganisms to employ (Figure 2) [54].

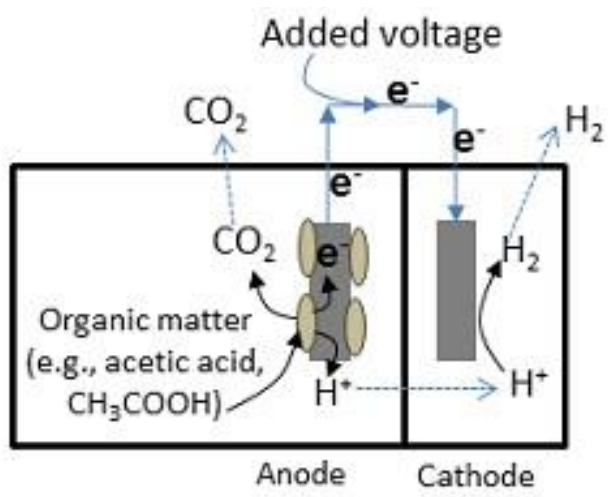

Figure 2. Microbial electrolysis cells [54].

\subsection{Thermochemical Water Spliting Cycles}

Thermochemical water splitting cycles (TWSCs) are a sequence of chemical processes that use heat energy to generate hydrogen and oxygen from water [55]. The temperature necessary for direct one-step water splitting is more than $2000{ }^{\circ} \mathrm{C}$, necessitating the use of a very high temperature heat source, and existing building materials are insufficiently resistant for this operation [56]. As a result, TWSCs with two or more stages have been studied and developed during the last 50 years. TWSCs are being researched in several categories, with different technologies being developed characterized by different number of stages and maximum operating temperature [57].

\section{Methods of Using Hydrogen in Engines}

Hydrogen may be utilized as a fuel in internal combustion engines; however, the combustion structure of the fuel can be altered with modest engine changes. The usage of hydrogen in an internal combustion engine is similar to that in other types of motors. In different investigations on the use of hydrogen in internal combustion gasoline engines within the automobile industry [58], hydrogen enters the combustion chamber of the motor via injection or carburetor frameworks from the premixed complex.

\subsection{Use of Hydrogen as a Direct Fuel}

Traditional engines typically run on liquid fuels like gasoline and diesel. There are a few motors that run on alternative fuels such as natural gas. Traditional engines cannot be utilized directly with hydrogen, unless the combustion systems are modified. To be able to combine various forms of electricity and hydrogen, a few novel ideas must be created [59]. 


\subsection{Use of Hydrogen as a Secondary Fuel}

Hydrogen can be used as a main or secondary fuel in internal combustion engines. Although there are certain disadvantages to employing hydrogen as a single fuel source, it is more suited in the current scenario [60]. Even if this technique does not eliminate reliance on fossil fuels, hydrogen will be utilized in conjunction with an economic shift in the fuel framework, and harmful exhaust emissions will be minimized [61].

\section{Methods to Provide Hydrogen to Internal Combustion Engines}

The construction of hydrogen engines is similar to that of ordinary internal combustion engines. However, to fix several issues, such as low power output, high $\mathrm{NO}_{\mathrm{x}}$ emissions, and irregular combustion, various changes to the fuel delivery system and combustion system are required [42]. To totally burn hydrogen, the air/fuel mass ratio must be 1:34, meaning 1 part hydrogen must be combined with 34 parts of air in the cylinder. Hydrogen makes up around $30 \%$ of the combustion chamber under stoichiometric circumstances [62].

As a result, three unique fuel delivery techniques were investigated in order to determine their potential as fuel cells.

\subsection{Fuel Carburetion Technique}

In hydrogen engines, the use of a gas carburetor, which is one of the oldest and most efficient techniques, offers advantages. Because a carburetor is often employed in a gasoline engine, the hydrogen fuel gasification process may be simply utilized to turn a widely used gasoline engine into a hydrogen engine.

The air-hydrogen mixture enters the intake manifold on a regular basis. A valve regulates the quantity of hydrogenated air to be combined, which powers the motor. Some engines need the addition of water. Steam and hydrogenated air are combined to increase engine performance, especially when the speed is too high. This is determined by the quantity of injected fuel. Because of the lower volumetric efficiency and system losses, the engine power is reduced by $15 \%$. This method may also produce engine pre-ignition, recoil, and knock since the ratio remains constant $[63,64]$. Figure 3 presents a schematic depiction of the fuel carburetion process in action [65].

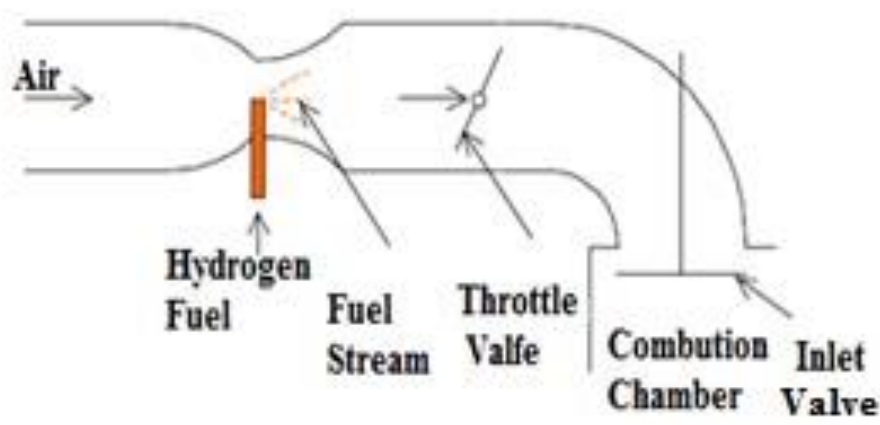

Figure 3. Fuel carburetion technique in action [65].

\subsection{Inlet Manifold and Inlet Port Injection Technique}

The intake port injection procedure is depicted in Figure 4. Hydrogen is delivered to the cylinder by mechanical or electrical injectors that may operate at varying rates and mixes with the air coming in through the intake manifold. The intake manifold plays a crucial role. The unfavorable effects of the carburizing technique, such as premature aging, shrinkage, and shock formation, were removed [66,67]. 


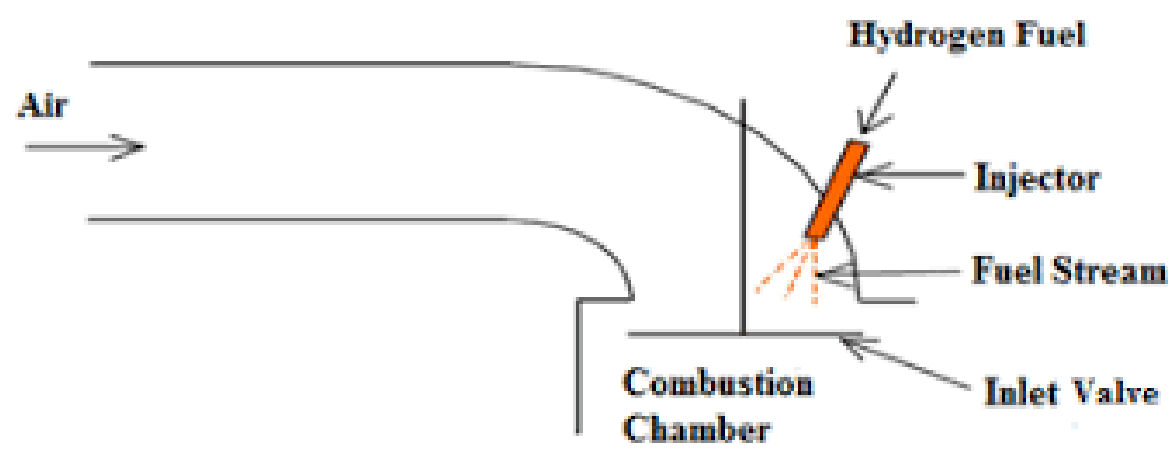

Figure 4. Inlet Manifold and Inlet Port Injection Method [67].

\subsection{Direct Injection Systems}

After the intake valve is closed, an air-fuel combination is formed in the combustion cylinder, which is a more technically sophisticated mechanism. After compression, hydrogen is delivered straight into the combustion chamber, similar to what achieved with numerous injections. Due to its fast diffusion, hydrogen will rapidly combine with air and can be utilized as a source of ignition for the spark plug [68]. The direct-injection hydrogen engine outperforms the other two technologies in terms of performance and efficiency. Furthermore, in hydrogen direct-injection engines, excessive auto-ignition temperature, pressure increase, and combustion delay may occur [69]. Figure 5 depicts the direct injection mode.

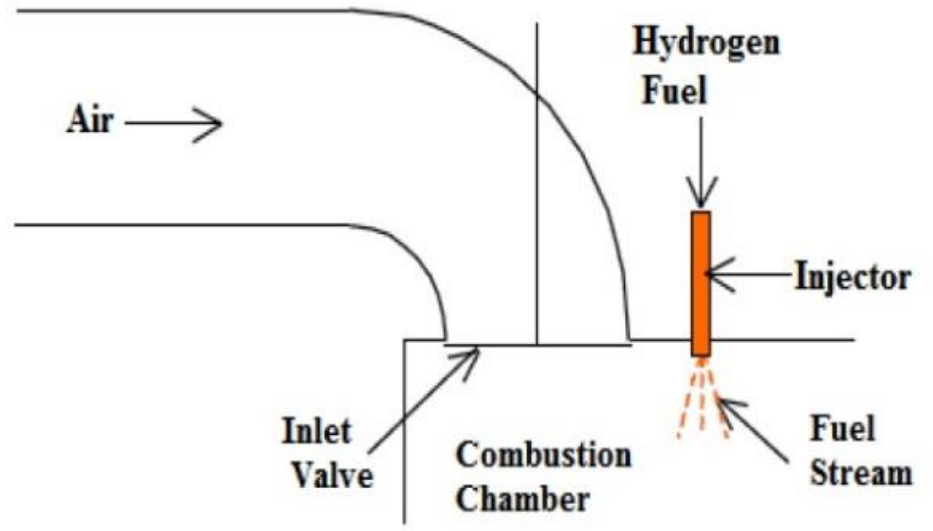

Figure 5. Direct Injection System [70].

\section{Impact of Hydrogen Fuels on the Performance of Internal Combustion (IC) Engines}

The use of hydrogen in gasoline engines has been extensively researched, and various modifications to these engines are required due to hydrogen's properties [62]. Previous research on hydrogen's usage in internal combustion engines has concentrated on combining hydrogen with gasoline or diesel fuel and evaluating the performance enhancement [71-74].

\subsection{Power and Torque}

Because the lower heat value (LHV) of hydrogen $(120 \mathrm{MJ} / \mathrm{kg})$ is larger than those of diesel $(43.6 \mathrm{MJ} / \mathrm{kg})$ and gasoline $(43.4 \mathrm{MJ} / \mathrm{kg})$ when used as an addition in spark ignition (SI) and compression ignition (CI) engines, hydrogen reduces the volumetric efficiency of the engine [75]. Inside the engine, hydrogen expands more than liquid fuels, thus reducing the volumetric efficiency of hydrogen engines. This is predictable, because the intake manifold generally heats up to help the evaporation of liquid fuels (diesel and gasoline). According to researchers, the stoichiometric composition of hydrogen-air fuel includes about $30 \%$ of hydrogen, and the ratio in volume of fully vaporized gasoline in gasoline and air mixtures is 20 [76,77]. This reduction in volumetric efficiency in a diesel engine 
using hydrogen based on the percentage of energy is shown in Figure 6 [78]. Figure 7 shows the same amount of reduction in a study on an SI engine using methane as the base fuel, with an LHV value close to that of gasoline (50) and hydrogen [79]. According to Figures 6 and 7, with the increase in the amount of hydrogen in the fuel, the amount of volumetric efficiency of the engine decreases, and the higher the amount of hydrogen, the greater the decrease in volumetric efficiency.

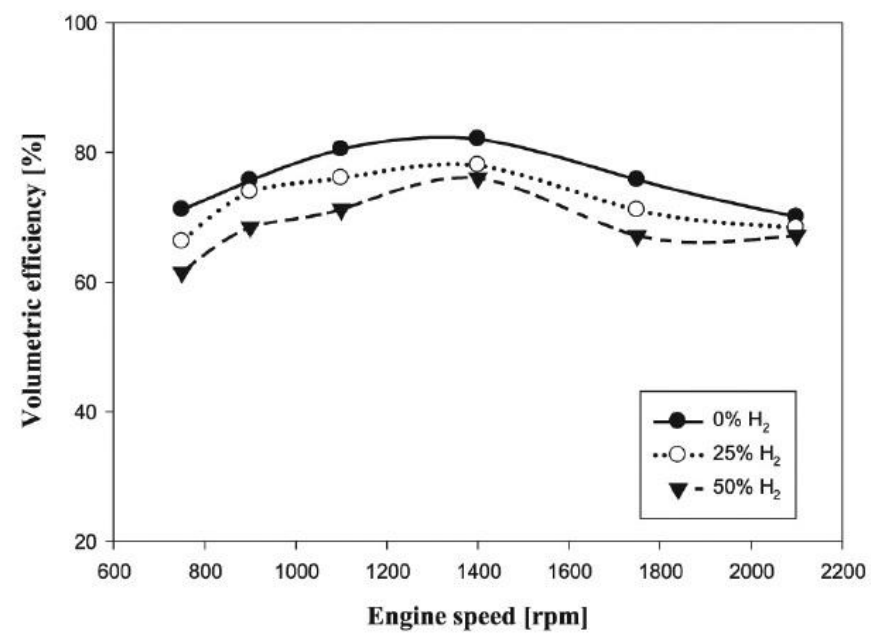

Figure 6. Volumetric efficiency changes with different percentages of hydrogen in the CI engine [78].

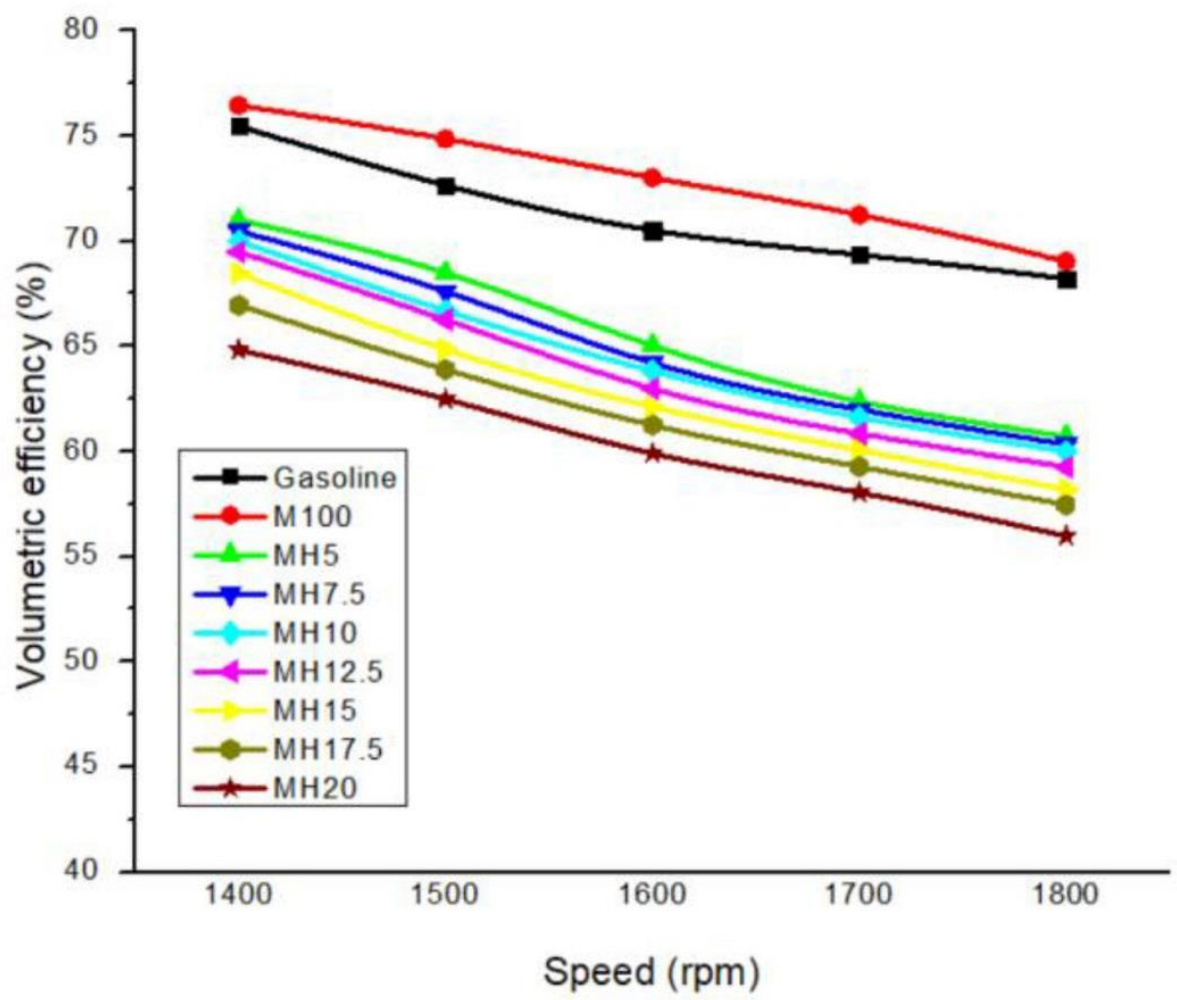

Figure 7. Volumetric efficiency changes with different percentages of hydrogen in the SI engine [79].

This reduction in volumetric efficiency will reduce engine power and torque. Figure 8 shows the amount of power and torque reduction in a CI engine using 25 and 50\% hydrogen [78]. As can be seen from the diagrams, with an increasing percentage of hydrogen, engine power and torque decrease. This power and torque reduction has also been reported for gasoline engines using hydrogen [80]. 

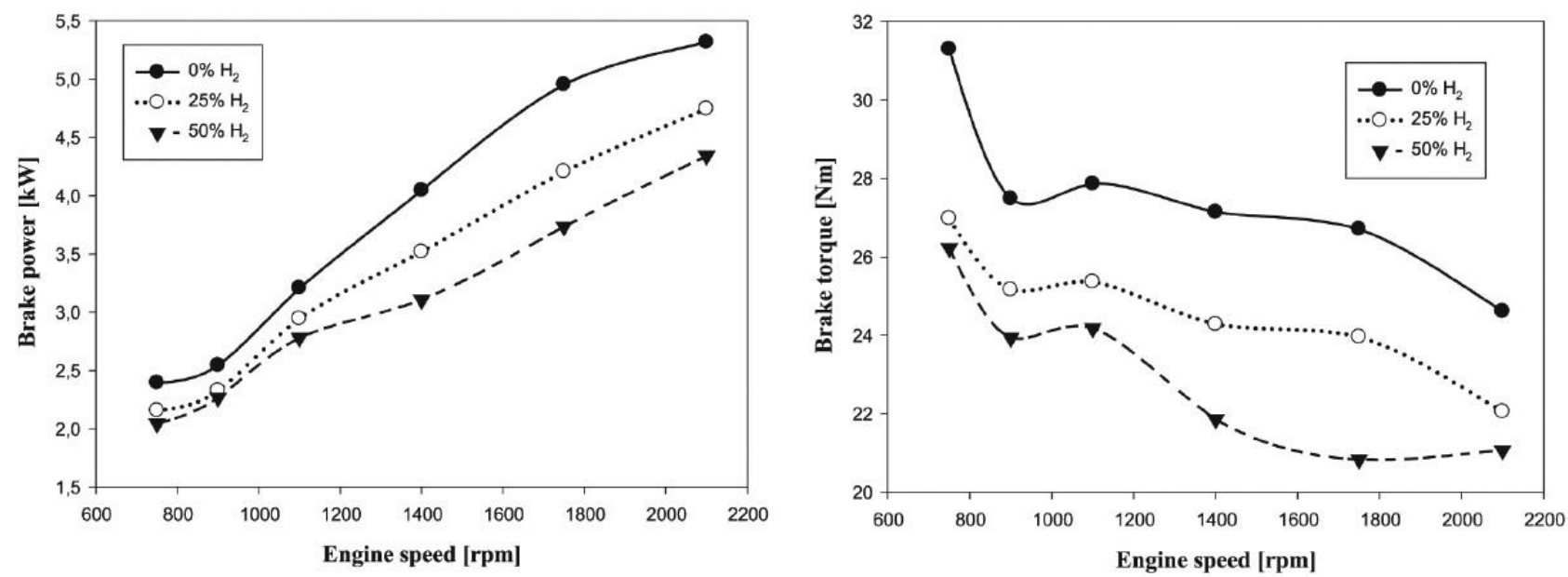

Figure 8. Brake power and brake torque changes with different percentages of hydrogen in the CI engine [73].

\subsection{Brake Thermal Efficiency}

Because of hydrogen's large molecular thermal capacity and the fact that adding hydrogen to internal combustion engines causes the combustion phase to shift and decreases combustion efficiency [78], as hydrogen is added to SI and CI engines, the fuel brake thermal efficiency (BTE) drops. Figure 9 shows the reduction in the amount of BTA in a CIA engine by adding hydrogen to the base fuel, which is diesel. Similar results have been reported by other researchers for the reduction of BTE in these engines [81,82].

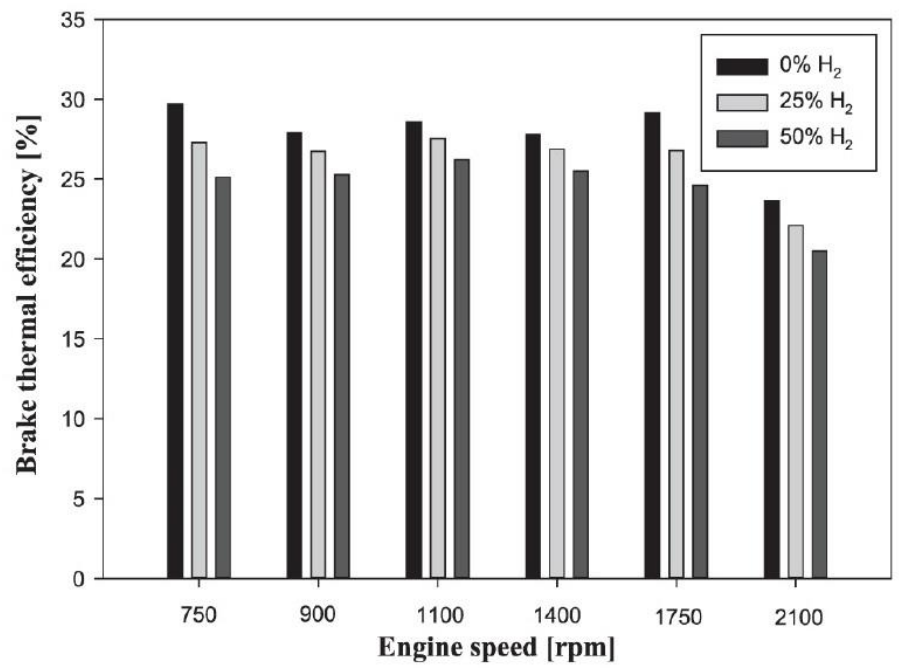

Figure 9. Brake thermal efficiency with different percentages of hydrogen in the $\mathrm{CI}$ engine [78].

Figure 10 shows the reduction in BTE in a methane-based SI engine with the addition of hydrogen.

Several aspects of hydrogen fuel are being investigated, including the addition of hydrogen to various fuels with varying operating characteristics. However, one of the essential characteristics to evaluate in a performance study is the change in compression ratio. Engines with greater operational compression ratios offer better thermal efficiency and higher power output according to prior research [71-74,83]. The hydrogen engine's power loss can be minimized by raising the compression ratio [84]. Other researchers have reported an increase in BTE as the compression ratio increases [80,85]. 


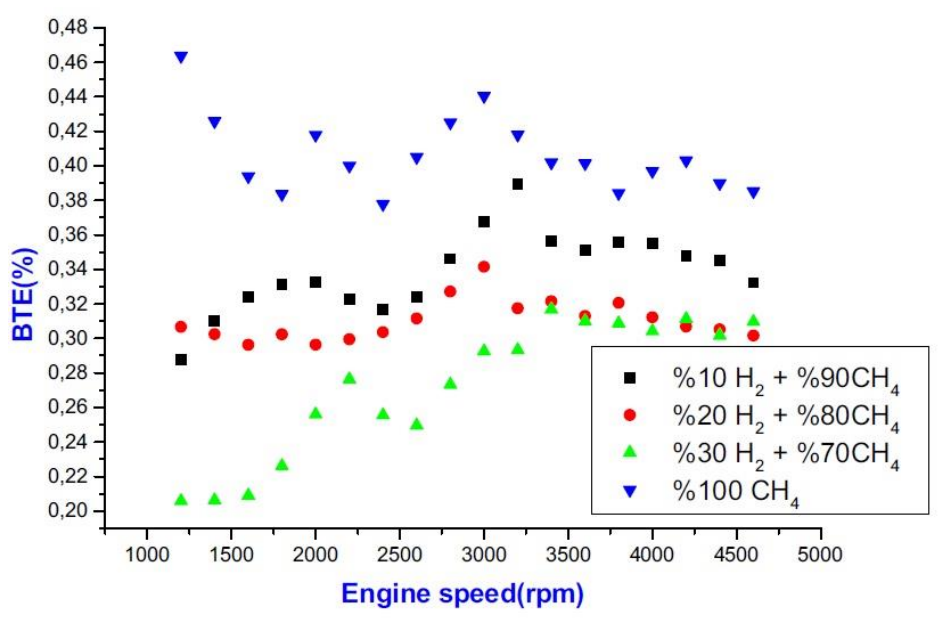

Figure 10. Brake thermal efficiency with different percentages of hydrogen in the SI engine [75].

\subsection{Brake-Specific Fuel Consumption}

In a diesel dual-fuel engine, hydrogen burns faster and has a nine-fold higher flame speed. The rate of heat release increases as the load and hydrogen substitution increase [86]. As a result, mixing hydrogen with diesel fuel in a CI engine raises the brake-specific fuel consumption. Figure 11 demonstrates how adding hydrogen to diesel fuel increases the quantity of BSFC produced at various speeds.

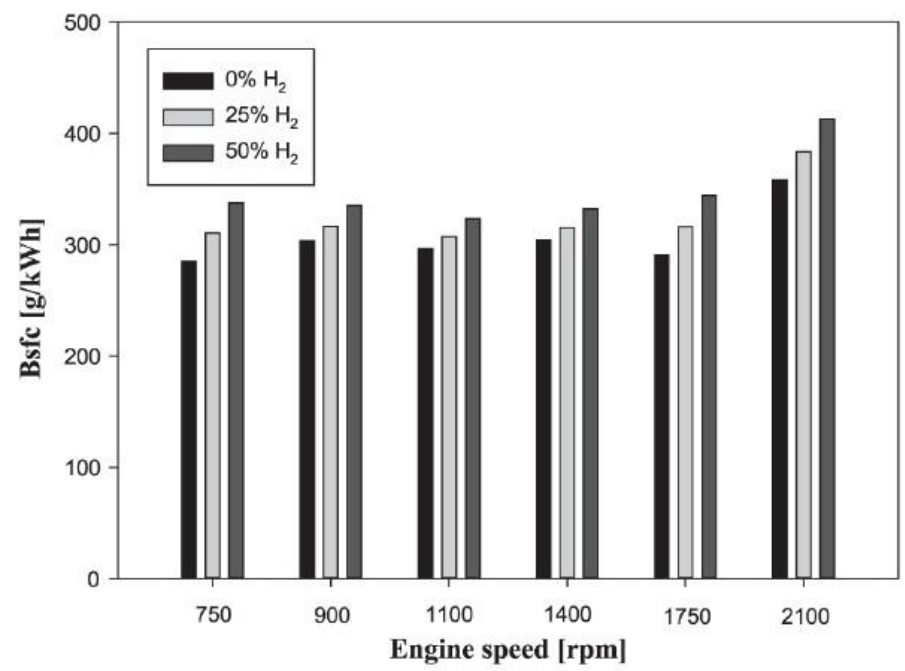

Figure 11. Brake thermal efficiency with different percentages of hydrogen in the SI engine [78].

By injecting hydrogen in varied hydrogen ratios, the equivalent brake-specific fuel consumption (BSFC) increases compared to what observed when using gasoline, due to the reduction in engine power (when hydrogen injection methods that lower engine power are utilized). Changing water injection and ignition times, on the other hand, can eliminate the degradation caused by hydrogen injection and successfully lower BSFC [87-91].

\section{Impact of Hydrogen Fuels on Emissions of Internal Combustion (IC) Engines}

The most hazardous pollutants generated by gasoline engines are $\mathrm{HC}, \mathrm{CO}$, and $\mathrm{NO}_{\mathrm{x}}$. Hydrogen has a number of unique combustion properties that aid in the full burning of gasoline [92]. Diesel engines produce more hazardous emissions including nitrogen oxides $\left(\mathrm{NO}_{\mathrm{x}}\right)$, unburned hydrocarbons (UHC), carbon monoxide $(\mathrm{CO})$, and soot. These contaminants have the potential to affect human health and the environment. Diesel engines also emit more pollutants than any other type of engine in the world, which makes them a major source of air pollution [92]. 
Hydrogen is used as a motor fuel because it decreases pollutants. In fact, hazardous chemicals are not produced as a result of hydrogen combustion. Various studies have focused on using hydrogen as a fuel in vehicles in the past 30 years [93,94].

\subsection{CO Emissions}

The emission of carbon monoxide (CO) causes holes in the ozone layer and is dangerous for the environment. Incomplete combustion in the engine will lead to the formation of carbon monoxide [95]. Adding hydrogen to internal combustion engines reduces the amount of carbon monoxide emissions in CI and SI engines. Because hydrogen is not a hydrocarbon fuel since its molecules lack carbon, increasing the hydrogen mass fraction in the fuel would lower the rate of hydrocarbon synthesis [96]. Furthermore, a high hydrogen flame raises cylinder pressure and improves combustion efficiency. Because of its high diffusion coefficient, pre-combustion hydrogen produces a more homogenous flammable mixture and improves oxygen availability. As a result of these factors, the amount of carbon monoxide produced by internal combustion engines is lowered [97]. Figures 12 and 13 show the reduction of carbon monoxide emissions using hydrogen as a fuel in diesel and gasoline engines, respectively.

\section{2. $\mathrm{CO}_{2}$ Emissions}

Carbon dioxide $\left(\mathrm{CO}_{2}\right)$ production can be caused by a lack of oxygen and a low temperature in the combustion chamber. This is harmful to the environment because of its influence on global warming [98]. The H/C rate increases when hydrogen is employed as a fuel in internal combustion engines, resulting in a reduction in combustion time and an increase in combustion efficiency [99]. Hydrogen, on the other hand, is a clean fuel that does not release $\mathrm{CO}_{2}$ and, therefore, lowers $\mathrm{CO}_{2}$ emissions [100]. Researchers have reported examples of emission reductions, as shown in Figures 14 and 15.

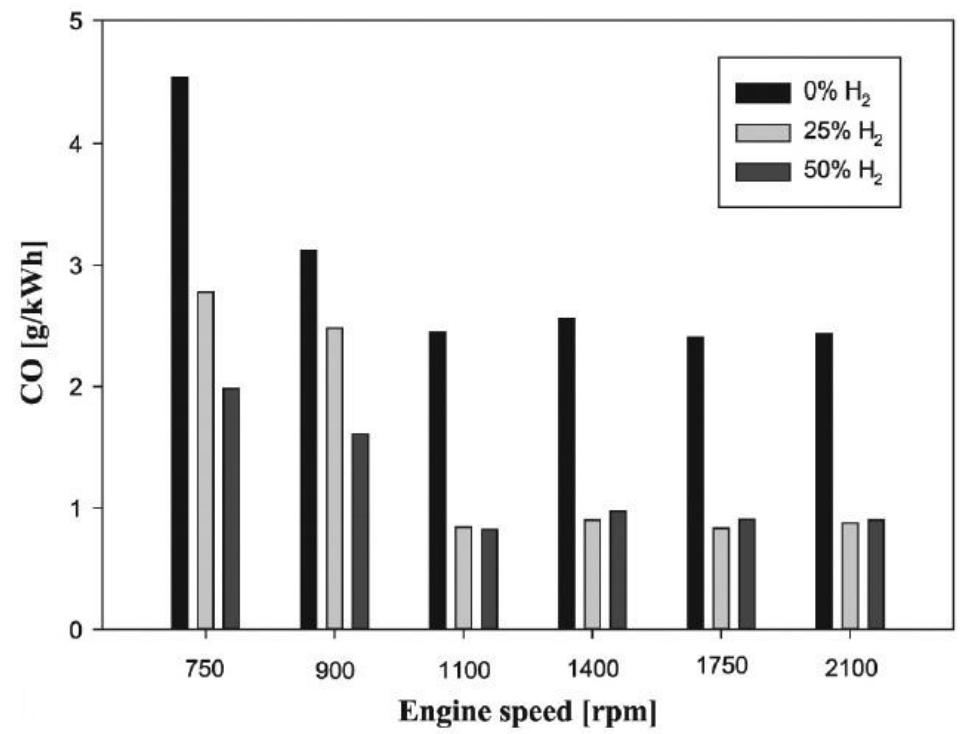

Figure 12. Reducing of $\mathrm{CO}$ emissions using hydrogen fuel in diesel engines [78]. 


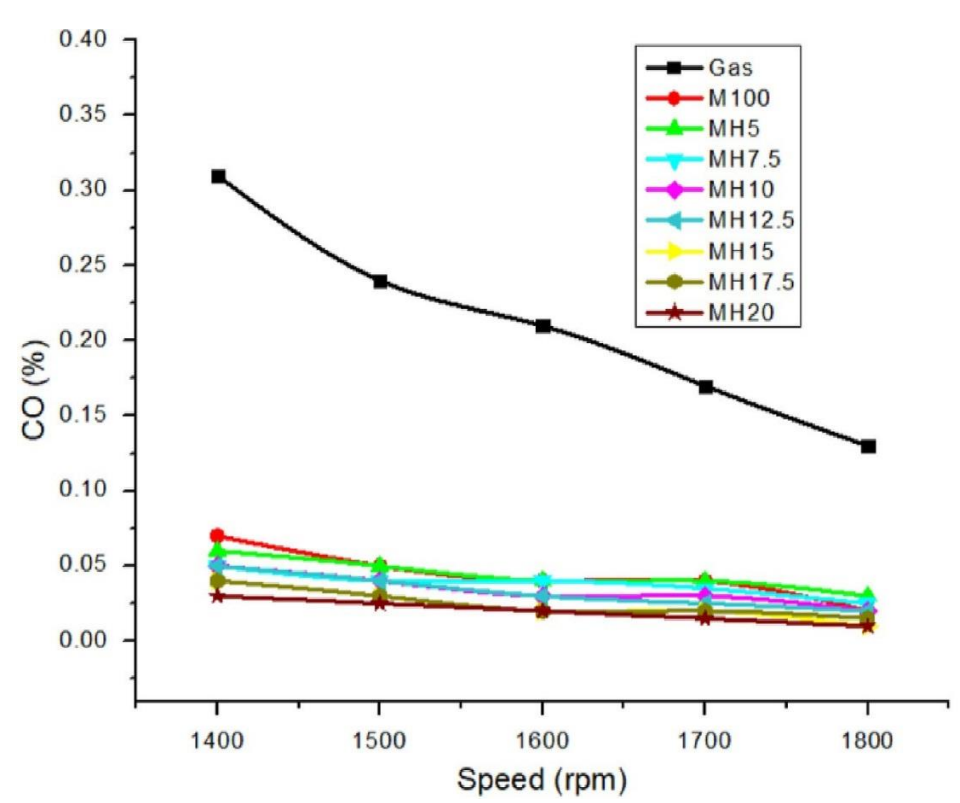

Figure 13. Reducing of $\mathrm{CO}$ emissions using hydrogen fuel in gasoline engines [79].

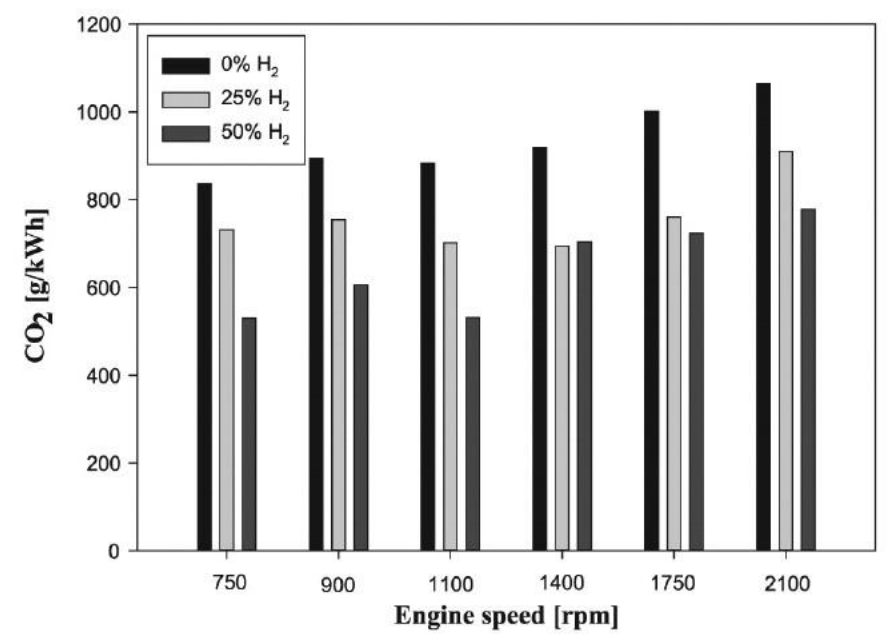

Figure 14. Reducing $\mathrm{CO}_{2}$ emission using hydrogen fuel in diesel engines [78].

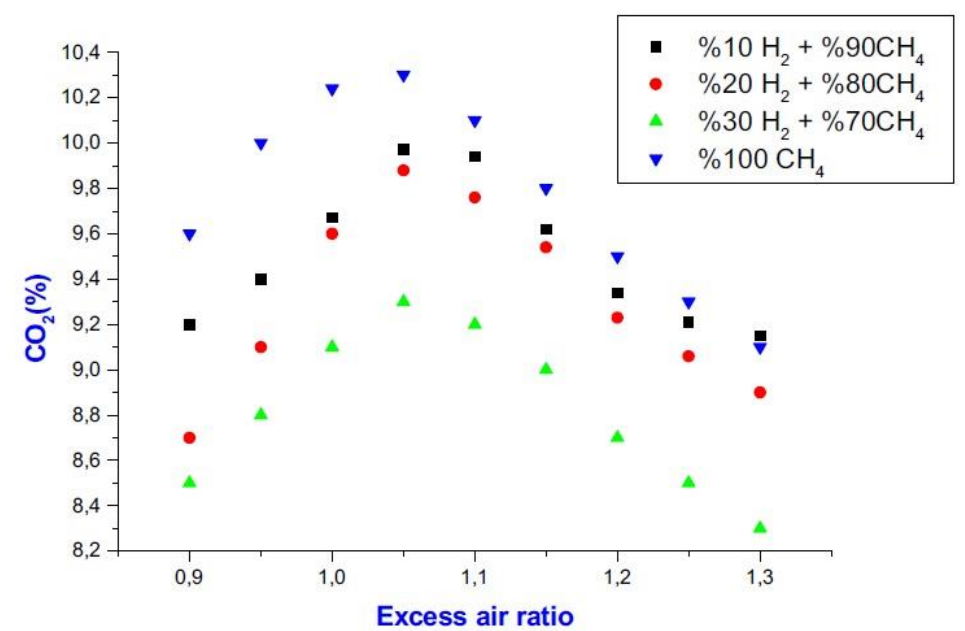

Figure 15. Reducing $\mathrm{CO}_{2}$ emission using hydrogen fuel in gasoline engines [75]. 


\subsection{UHC Emissions}

Hydrocarbons that do not burn completely in the combustion process inside the combustion chamber will emit unburned hydrocarbon (UHC) in the exhaust gases [35]. As mentioned, adding hydrogen to the fuel will homogenize the mixture and increase the flame speed. In addition, due to the lack of hydrocarbons in hydrogen fuel, its addition to combustion engine fuels will reduce the emission of unburned hydrocarbons. Reduced emissions of unburned hydrocarbons can be seen in Figures 16 and 17 for diesel and gasoline engines.

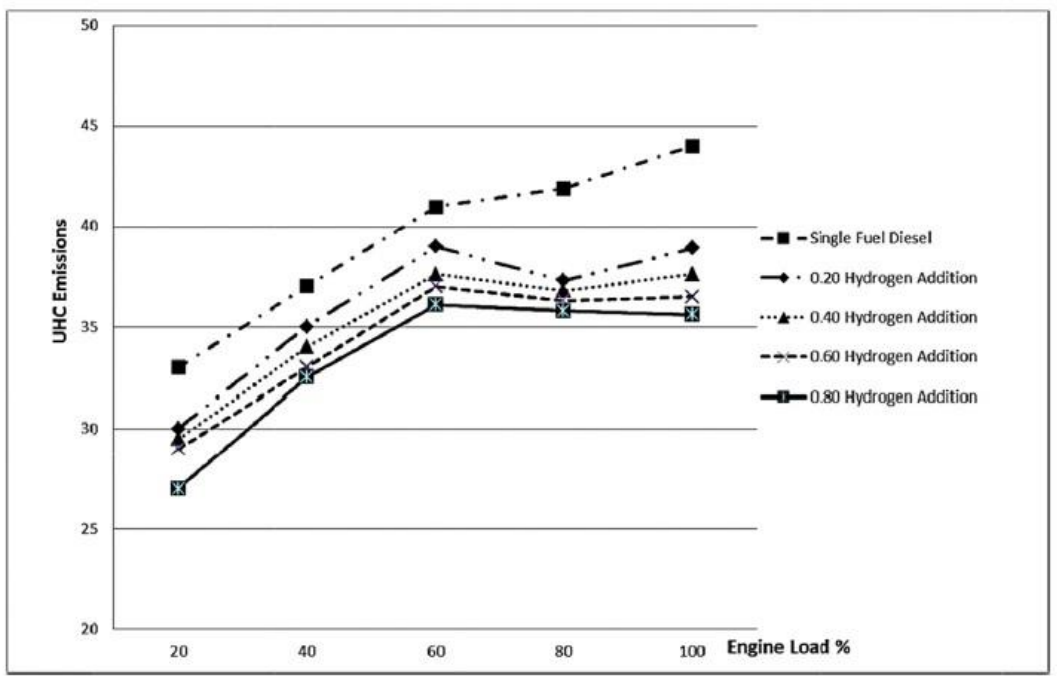

Figure 16. Reducing UHC emissions using hydrogen fuel in diesel engines [85].

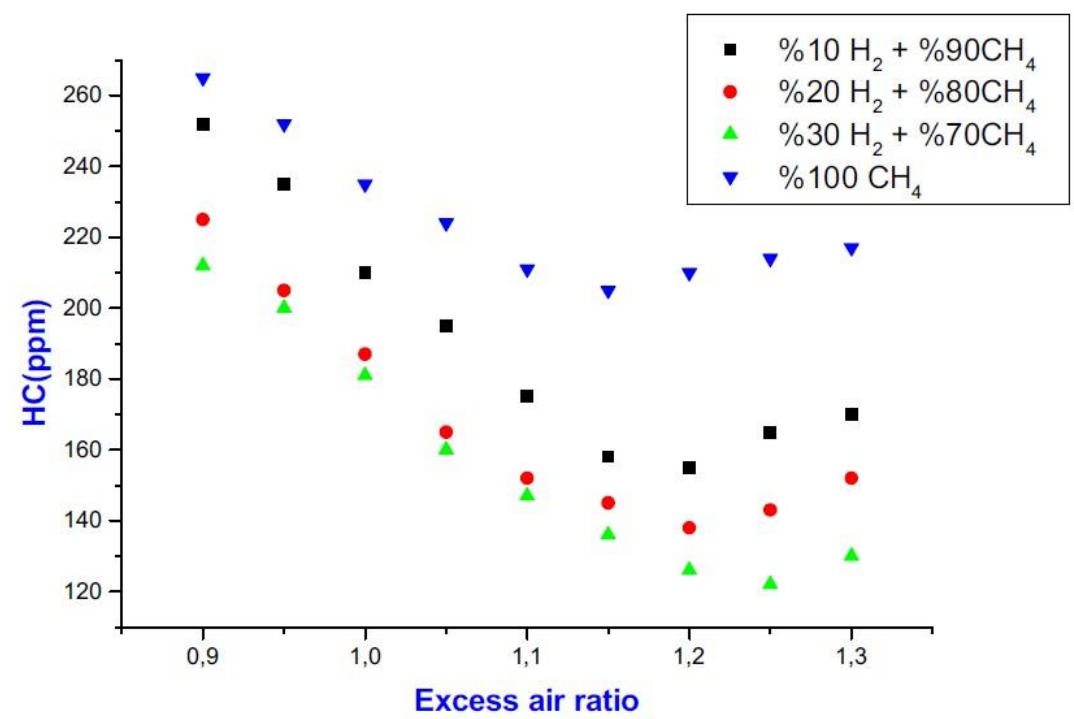

Figure 17. Reducing UHC emissions using hydrogen fuel in gasoline engines [75].

\section{4. $\mathrm{NO}_{x}$ Emissions}

Nitrogen oxides are produced by the high temperatures achieved during the combustion process in the combustion chamber. Some nitrogen in the air combines with oxygen in the presence of heat. The air/fuel ratio, compression ratio, engine speed, ignition timing, and thermal dilution have an effect on the amount of $\mathrm{NO}_{x}$ produced [101,102].

Because of its features such as fast flame speed, low ignition energy required, and high adiabatic temperature, hydrogen is regarded as a suitable fuel for combustion. These 
features contribute to a rise in the temperature of the working fluid in the cylinder as well as to an increase in $\mathrm{NO}_{\mathbf{x}}$ (Figures 18 and 19).

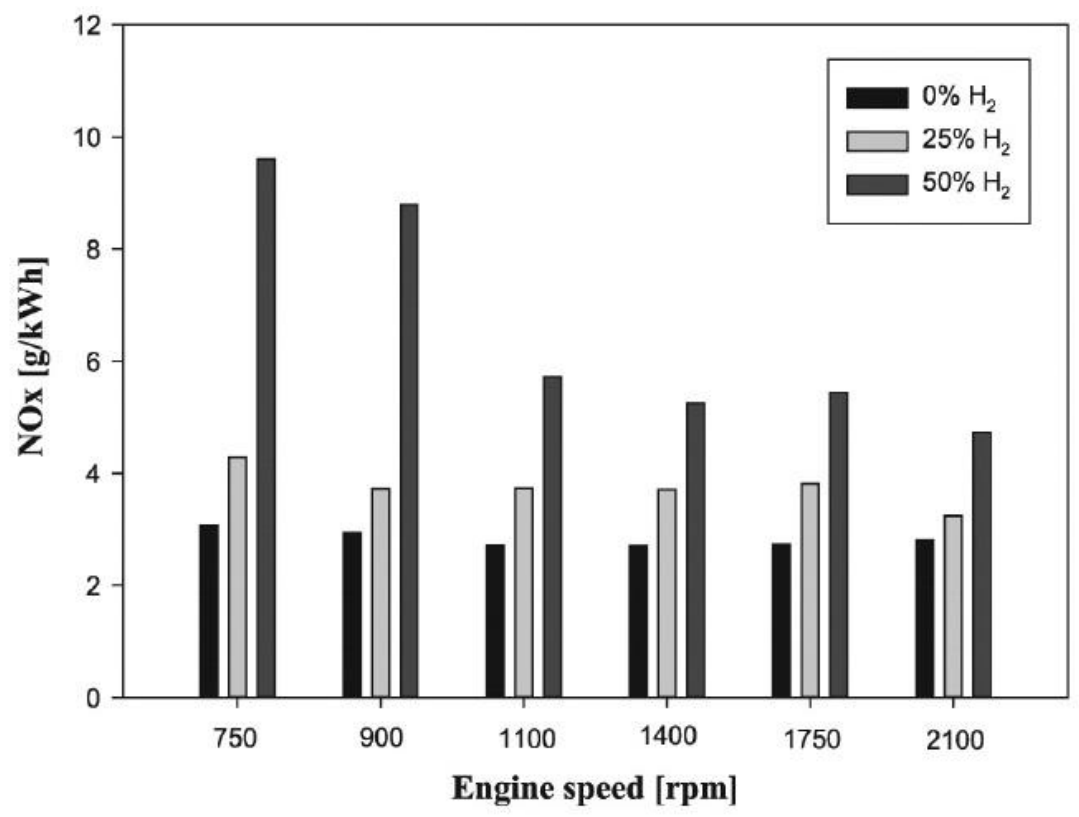

Figure 18. Increase of $\mathrm{NO}_{x}$ emissions using hydrogen fuel in diesel engines [78].

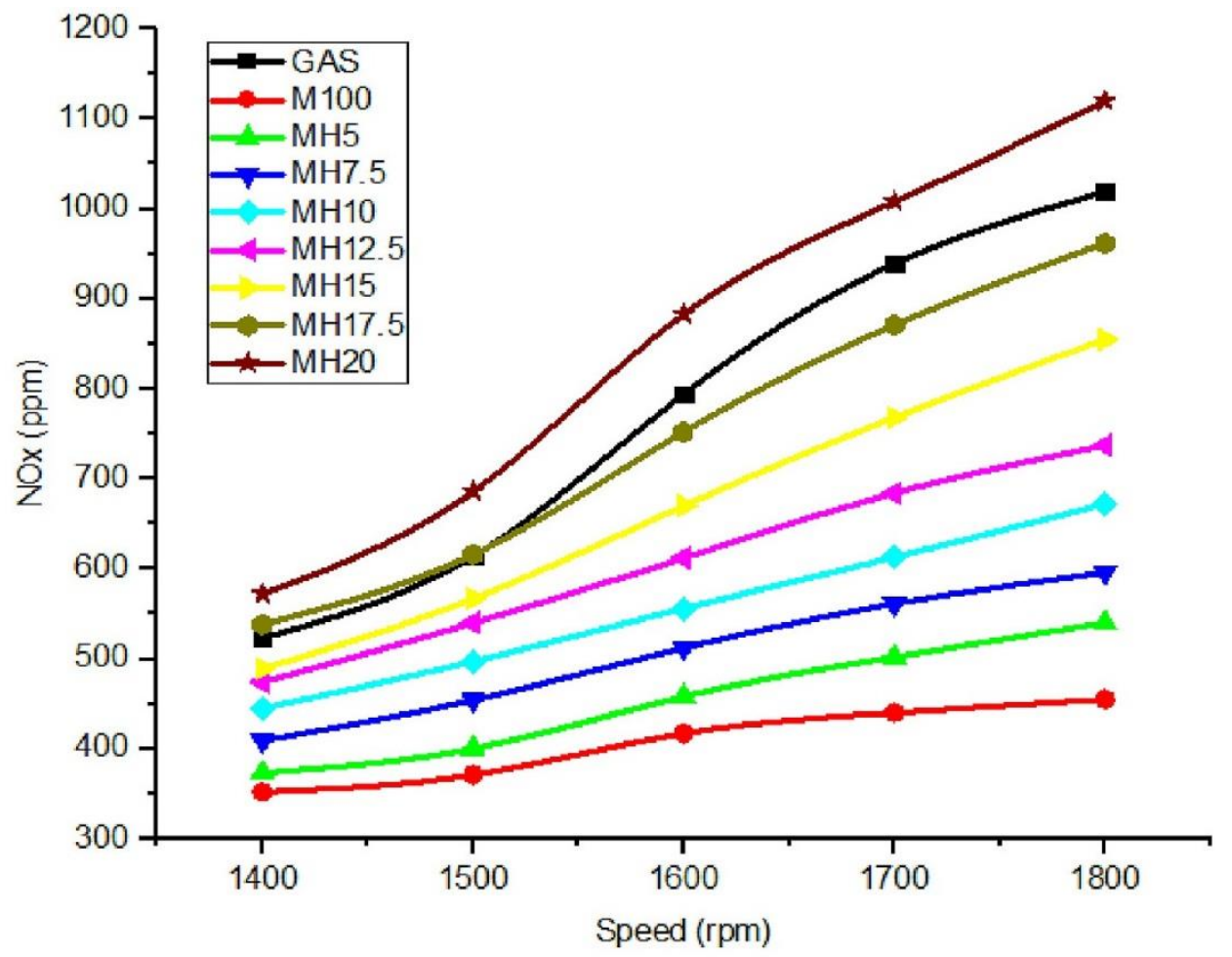

Figure 19. Increase of $\mathrm{NO}_{x}$ emissions using hydrogen fuel in gasoline engines [85].

\subsection{Soot Emissions}

Soot emission is specific to diesel engines. Due to the heterogeneous nature of diesel combustion, there is a wide distribution of fuel/air ratios within the cylinder. Soot formation mainly takes place in the fuel-rich zone at high temperature and high pressure. Soot is typical to fuel-air mixtures that are too lean to auto-ignite or to support a propagating flame. It can also be caused by fuel-air mixtures that are too rich to ignite [103]. 
The high coefficient of hydrogen emission and the great access of fuel to oxygen will increase the homogeneity of the flammable mixture and the amount of $\mathrm{H} / \mathrm{C}$ in the total fuel, which will reduce soot in diesel engines [104]. Figure 20 shows examples of soot reduction using hydrogen in diesel engines.

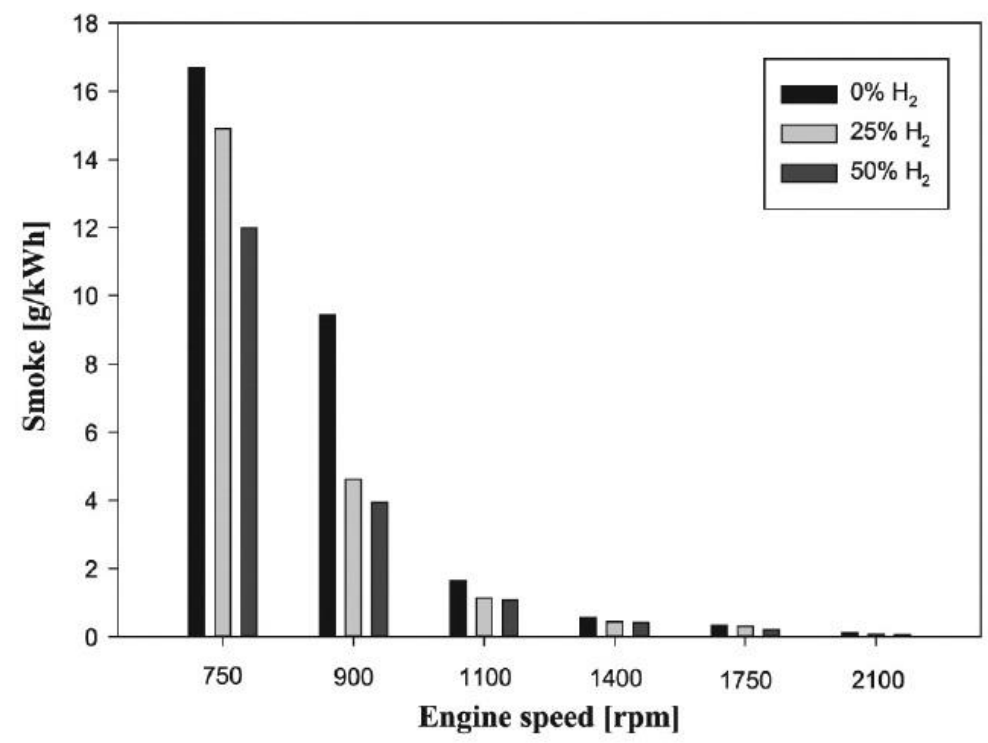

Figure 20. Increase of $\mathrm{NO}_{x}$ emissions using hydrogen fuel in diesel engines [61].

\section{Conclusions}

Energy should be cleaner and more efficient in the future. In comparison with other alternative fuels, hydrogen is the most effective to reduce or eliminate harmful vehicle emissions and their environmental impact. Because hydrogen is one of the numerous elements found in the atmosphere, it is readily available and one of the most useful alternatives to fossil fuels today. Currently, the most used technique for hydrogen generation is steam-methane reforming.

In this review, the effect of adding hydrogen as a fuel on the performance and exhaust emissions of spark ignition (SI) and compression ignition (CI) engines was investigated. The following results were obtained after reviewing the literature:

1. When hydrogen is used as an additive in spark ignition (SI) and compression ignition (CI) engines, it will reduce the volumetric efficiency of the engine because the lower heat value $(\mathrm{LHV})$ of hydrogen $(120 \mathrm{MJ} / \mathrm{kg})$ is higher than those of diesel $(43.6 \mathrm{MJ} / \mathrm{kg})$ and gasoline $(43.4 \mathrm{MJ} / \mathrm{kg})$. This reduction in volumetric efficiency will reduce engine power and torque.

2. Due to the high molecular thermal capacity of hydrogen and to the fact that with the addition of hydrogen in internal combustion engines, the progress of the combustion phase changes and reduces the combustion efficiency, in SI and CI engines the addition of hydrogen as a fuel decreases brake thermal efficiency (BTE).

3. Hydrogen burns quickly and has a nine-fold faster flame speed in a diesel dual-fuel engine. The heat release rate rises as the load rises and hydrogen substitution rises. For this reason, adding hydrogen to diesel fuel in $\mathrm{CI}$ engines increases brake-specific fuel consumption (BSFC). By injecting hydrogen at varied ratios, the equivalent brakespecific fuel consumption (BSFC) increases compared to what observed when using gasoline due to the reduction in engine power (when hydrogen injection methods that lower engine power are utilized).

4. Adding hydrogen to internal combustion engines reduces the amount of carbon monoxide emissions from CI and SI engines. Because hydrogen is not a hydrocarbon fuel since its molecule lacks carbon, increasing the hydrogen mass fraction in the fuel will lower the rate of hydrocarbon synthesis. Furthermore, a high hydrogen flame 
raises the cylinder's pressure and improves combustion efficiency. Because of its high diffusion coefficient, pre-combustion hydrogen produces a more homogenous flammable mixture and improves oxygen availability. As a result of these factors, the amounts of carbon monoxide (CO) and unburned hydrocarbon (UHC) produced by internal combustion engines are lowered.

5. When hydrogen is used as a fuel in internal combustion engines, the $\mathrm{H} / \mathrm{C}$ rate rises, resulting in a decrease in combustion time and an improvement in combustion efficiency. On the other hand, because hydrogen is a clean fuel, it does not emit $\mathrm{CO}_{2}$, and its usage reduces $\mathrm{CO}_{2}$ emissions.

6. Because of its features such as fast flame speed, low ignition energy required, and high adiabatic temperature, hydrogen is regarded as a suitable fuel for combustion. These features contribute to a rise in the temperature of the working fluid in the cylinder as well as to an increase in $\mathrm{NO}_{\mathrm{x}}$.

7. The high coefficient of hydrogen emission and the greater access of fuel to oxygen will increase the homogeneity of the flammable mixture and the amount of $\mathrm{H} / \mathrm{C}$ in the total fuel, which will reduce the soot in diesel engines.

8. With the usage of hydrogen in the majority of internal combustion engines, hazardous exhaust pollutants are reduced, and engines' overall performance improves. When considering its environmental and economic benefits, hydrogen is a clean and sustainable energy source.

Author Contributions: Conceptualization, B.S.; methodology, G.N. and T.Y.; validation, B.S., T.Y. and G.N.; formal analysis, G.N. and T.Y.; investigation, B.S.; resources, B.S. and T.Y.; data curation, B.S. and T.Y.; writing — original draft preparation, B.S.; writing—review and editing, B.S. and T.Y.; visualization, B.S.; supervision, B.S.; project administration, B.S. All authors have read and agreed to the published version of the manuscript.

Funding: This research received no external funding.

Institutional Review Board Statement: Not applicable.

Informed Consent Statement: Not applicable.

Data Availability Statement: The data presented in this study are available on request from the corresponding author. Please contact to b.shadidi@basu.ac.ir.

Acknowledgments: This research was conducted in collaboration with the Faculty of Agriculture, Bu Ali Sina University.

Conflicts of Interest: The funders had no role in the design of the study; in the collection, analyses, or interpretation of data; in the writing of the manuscript, or in the decision to publish the results.

\section{References}

1. Hosseini, S.E.; Butler, B. An overview of development and challenges in hydrogen powered vehicles. Int. J. Green Energy 2020, 17, 13-37. [CrossRef]

2. Shadidi, B.; Yusaf, T.; Alizadeh, H.H.A.; Ghobadian, B. Experimental investigation of the tractor engine performance using diesohol fuel. Appl. Energy 2014, 114, 874-879. [CrossRef]

3. Short-Term Energy Outlook. Available online: https://www.eia.gov/outlooks/steo/report/global_oil.php (accessed on 7 July 2021).

4. Demirbas, A. Biohydrogen; Springer Publishing Co: London, UK, 2009.

5. Chang, X.; Ma, T.; Wu, R. Impact of urban development on residents' public transportation travel energy consumption in China: An analysis of hydrogen fuel cell vehicles alternatives. Int. J. Hydrogen Energy 2019, 44, 16015-16027. [CrossRef]

6. How Many Cars Are There in the World Today? Available online: https://www.rfidtires.com/how-many-cars-world.html (accessed on 24 October 2018).

7. World Business Council for Sustainable Development (WBCSD). Mobility 2030: Meeting the Challenges to Sustainability. The Sustainable Mobility Project; World Business Council for Sustainable Development (WBCSD): Geneva, Switzerland, 2004.

8. Ettefaghi, E.; Ghobadian, B.; Rashidi, A.; Najafi, G.; Khoshtaghaza, M.H.; Rashtchi, M. A novel bio-nano emulsion fuel based on biodegradable nanoparticles to improve diesel engines performance and reduce exhaust emissions. Renew. Energy 2018, 125, 64-72. [CrossRef] 
9. Najafi, G.; Ghobadian, B.; Yusaf, T.F.; Rahimi, H. Combustion analysis of a CI engine performance using waste cooking biodiesel fuel with an artificial neural network aid. Am. J. Appl. Sci. 2007, 4, 759-767. [CrossRef]

10. Yusaf, T.; Hamawand, I.; Baker, P.; Najafi, G. The effect of methanol-diesel blended ratio on ci engine performance. Int. J. Automot. Mech. Eng. 2013, 8, 1385-1395. [CrossRef]

11. Das, L.M. 7-Hydrogen-fueled internal combustion engines. In Woodhead Publishing Series in Energy. Compendium of Hydrogen Energy; Barbir, F., Basile, A., Veziroğlu, T.N., Eds.; Woodhead Publishing: Sawston, UK, 2016; pp. 177-217.

12. Ali, O.M.; Mamat, R.; Najafi, G.; Yusaf, T.; Ardebili, S.M.S. Optimization of biodiesel-diesel blended fuel properties and engine performance with ether additive using statistical analysis and response surface methods. Energies 2015, 8, 14136-14150. [CrossRef]

13. Yasin, M.H.M.; Mamat, R.; Najafi, G.; Ali, O.M.; Yusop, A.F.; Ali, M.H.J.R. Potentials of palm oil as new feedstock oil for a global alternative fuel: A review. Renew. Sustain. Energy Rev. 2017, 79, 1034-1049. [CrossRef]

14. Awad, O.I.; Ali, O.M.; Mamat, R.; Abdullah, A.; Najafi, G.; Kamarulzaman, M. Using fusel oil as a blend in gasoline to improve SI engine efficiencies: A comprehensive review. Renew. Sustain. Energy Rev. 2017, 69, 1232-1242. [CrossRef]

15. Yazid, M.N.A.W.M.; Sidik, N.A.C.; Mamat, R.; Najafi, G.; Transfer, M. A review of the impact of preparation on stability of carbon nanotube nanofluids. Int. Comun. Heat Mass Transf. 2016, 78, 253-263. [CrossRef]

16. Hosseini, S.E.; Wahid, M.A.; Ganjehkaviri, A. An overview of renewable hydrogen production from thermochemical process of oil palm solid waste in Malaysia. Energy Convers. Manag. 2015, 94, 415-429. [CrossRef]

17. Safari, F.; Dincer, I. A review and comparative evaluation of thermochemical water splitting cycles for hydrogen production. Energy Convers. Manag. 2020, 205, 112182. [CrossRef]

18. Shivaprasad, K.; Kumar, G.; Guruprasad, K. Performance, emission and fuel induction system of hydrogen fuel operated spark ignition engine-A review. Int. J. Mod. Eng. Res. 2012, 2, 565-571.

19. Fayaz, H.; Saidur, R.; Razali, N.; Anuar, F.S.; Saleman, A.R.; Islam, M.R. An overview of hydrogen as a vehicle fuel. Int. J. Hydrogen Energy 2012, 16, 5511-5528. [CrossRef]

20. Zeng, K.; Zhang, D. Recent progress in alkaline water electrolysis for hydrogen production and applications. Prog. Energy Combust. Sci. 2010, 36, 307-326. [CrossRef]

21. Pagliaro, M.; Konstandopoulos, A.G. Solar Hydrogen: Fuel of the Future; Royal Society of Chemistry: Cambridge, UK, 2012.

22. Balat, M.; Balat, M. Political, economic and environmental impacts of biomass-based hydrogen. Int. J. Hydrogen Energy 2010, 34, 3589-3603. [CrossRef]

23. Wallington, T.J.; Lambert, C.K.; Ruona, W.C. Diesel vehicles and sustainable mobility in the U.S. Energy Pol. 2013, 54, 47-53. [CrossRef]

24. Mwangi, J.K.; Lee, W.-J.; Chang, Y.-C.; Chen, C.-Y.; Wang, L.-C. An overview: Energy saving and pollution reduction by using green fuel blends in diesel engines. Appl. Energy 2015, 159, 214-236. [CrossRef]

25. Gill, S.S.; Tsolakis, A.; Herreros, J.M.; York, A.P.E. Diesel emissions improvements through the use of biodiesel or oxygenated blending components. Fuel 2012, 95, 578-586. [CrossRef]

26. Staffell, I.; Scamman, D.; Abad, A.V.; Balcombe, P.; Dodds, P.E.; Ekins, P.; Shahd, N.; Ward, K.R. The role of hydrogen and fuel cells in the global energy system. Energy Environ. Sci. 2019, 12, 463-491. [CrossRef]

27. Reitz, R.D. Directions in internal combustion engine research. Combust Flame 2013, 160, 1-8. [CrossRef]

28. White, C.M.; Steeper, R.R.; Lutz, A.E. The hydrogen-fueled internal combustion engine: A technical review. Int. J. Hydrogen Energy 2006, 31, 1292-1305. [CrossRef]

29. Kahraman, E.; Ozcanl1, S.C.; Ozerdem, B. An experimental study on performance and emission characteristics of a hydrogen fuelled spark ignition engine. Int. J. Hydrogen Energy 2007, 32, 2066-2072. [CrossRef]

30. Jingding, L.; Linsong, G.; Tianshen, D. Formation and restraint of toxic emissions in hydrogen-gasoline mixture fueled engines. Int. J. Hydrogen Energy 1998, 23, 971-975. [CrossRef]

31. King, R.; Rand, M. The hydrogen engine. Can. J. Technol. 1955, 33, 44569. [CrossRef]

32. Ji, C.; Wang, S. Effect of hydrogen addition on combustion and emissions performance of a spark ignition gasoline engine at lean conditions. Int. J. Hydrogen Energy 2009, 34, 7823-7834. [CrossRef]

33. Das, L.M. Hydrogeneoxygen reaction mechanism and its implication to hydrogen engine combustion. Int. J. Hydrogen Energy 1996, 21, 703-715. [CrossRef]

34. Andrea, T.D.; Henshaw, P.F.; Ting, D.S.K. The addition of hydrogen to a gasoline-fuelled SI engine. Int. J. Hydrogen Energy 2004, 29, 1541-1552. [CrossRef]

35. Heywood, J.B. Internal Combustion Engine Fundamentals; McGraw-Hill Book Co: New York, NY, USA, 1988.

36. Padiyar, S. Properties of hydrogen. In Proceedings of Summer School of Hydrogen Energy; IIT Madras: Chennai, India, 1985.

37. Li, H.; Karim, G.A. An Experimental Investigation of S.I. Engine operation on gaseous fuels lean mixtures. SAE Trans. 2005, 114, 1600-1608.

38. Duan, J.; Liu, F.; Sun, B. Backfire control and power enhancement of a hydrogen internal combustion engine. Int. J. Hydrogen Energy 2014, 39, 4581-4589. [CrossRef]

39. Ji, C.; Wang, S. Effect of hydrogen addition on the idle performance of a spark ignited gasoline engine at stoichiometric condition. Int. J. Hydrogen Energy 2009, 34, 3546-3556. [CrossRef]

40. Salek, F.; Zamen, M.; Hosseini, S.V. Experimental study, energy assessment and improvement of hydroxyl generator coupled with a gasoline engine. Energy Rep. 2020, 6, 146-156. [CrossRef] 
41. Salek, F.; Zamen, M.; Hosseini, S.V.; Babaie, M. Novel hybrid system of pulsed HHO generator/TEG waste heat recovery for CO reduction of a gasoline engine. Int. J. Hydrogen Energy 2020, 45, 23576-23586. [CrossRef]

42. Faizal, M.; Chuah, L.; Lee, C.; Hameed, A.; Lee, J.; Shankar, M. Review of hydrogen fuel for internal combustion engines. J. Mech. Eng. Res. Dev. 2019, 42, 35-46.

43. Kojima, Y.; Kawai, Y.; Kimbara, M.; Nakanishi, H.; Matsumoto, S. Hydrogen Generation by Hydrolysis Reaction of Lithium Borohydride. Int. J. Hydrogen Energy 2004, 29, 1213-1217. [CrossRef]

44. Estimating the Carbon Footprint of Hydrogen Production. Available online: https://www.forbes.com/sites/scottmendelson (accessed on 21 August 2020).

45. Hydrogen Production: Natural Gas Reforming. Available online: https://www.energy.gov/eere/fuelcells/hydrogen-productionnatural-gas-reforming (accessed on 3 August 2021).

46. Hydrogen Production: Electrolysis. Available online: https://www.energy.gov/eere/fuelcells/hydrogen-production-electrolysis (accessed on 8 August 2021).

47. Ozturk, M.; Dincer, I. A comprehensive review on power-to-gas with hydrogen options for cleaner applications. Int. J. Hydrogen Energy 2021, 46, 31511-31522. [CrossRef]

48. Safari, F.; Dincer, I. Assessment and optimization of an integrated wind power system for hydrogen and methane production. Energy Convers. Manag. 2018, 177, 693-703. [CrossRef]

49. Explainer: How do We Make Hydrogen from Coal, and Is It Really a Clean Fuel? Available online: https://theconversation.com/ explainer-how-do-we-make-hydrogen-from-coal-and-is-it-really-a-clean-fuel94911\#: :text=To\%20produce\%20hydrogen \%20 from $\% 20$ coal, heat\%20for\%20the\%20gasification\%0reaction (accessed on 13 April 2018).

50. Hydrogen Production: Biomass Gasification. Available online: https://www.energy.gov/eere/fuelcells/hydrogen-productionbiomass-gasification (accessed on 5 August 2021).

51. Hydrogen Production: Biomass-Derived Liquid Reforming. Available online: https://www.energy.gov/eere/fuelcells/hydrogenproduction-biomass-derived-liquid-reforming (accessed on 22 August 2021).

52. Safari, F.; Norouzi, O.; Tavasoli, A. Hydrothermal gasification of Cladophora glomerata macroalgae over its hydrochar as a catalyst for hydrogen-rich gas production. Bioresour. Technol. 2016, 222, 232-241. [CrossRef]

53. Safari, F.; Javani, N.; Yumurtaci, Z. Hydrogen production via supercritical water gasification of almond shell over algal and agricultural hydrochars as catalysts. Int. J. Hydrogen Energy 2018, 43, 1071-1080. [CrossRef]

54. Hydrogen Production: Microbial Biomass Conversion. Available online: https://www.energy.gov/eere/fuelcells/hydrogenproduction-microbial-biomass-conversion (accessed on 17 August 2021).

55. Dincer, I.; Zamfirescu, C. Sustainable Hydrogen Production; Elsevier: Amesterdam, NL, USA, 2017.

56. Hoskins, A.L.; Millican, S.L.; Czernik, C.E. Continuous on-sun solar thermochemical hydrogen production via an isothermal redox cycle. Appl. Energy 2019, 249, 368-376. [CrossRef]

57. Safari, F.; Dincer, I. A study on the $\mathrm{Fe}-\mathrm{Cl}$ thermochemical water splitting cycle for hydrogen production. Int. J. Hydrogen Energy 2020, 45, 18867-18875. [CrossRef]

58. Tsujimura, T.; Mikami, S.; Achicha, N.; Tokunaga, Y.; Senda, J.; Fujimoto, H. A study of direct injection diesel engine fueled with hydrogen. SAE Trans. 2003, 112, 390-405.

59. Dipioglu, I. Investigation of Production of Hydrogen on Vehicle and Usage of Internal Combustion Engines with Petroleum Origin Fuels. Master's Thesis, G.U., Turkey, 1998.

60. Murcak, A. Experimental Analysis of the Effect of Hydrogen Fuel on Diesel Engine Performance and Exhaust Emissions. Master's Thesis, Automotive Department, S.U., Turkey, 2003.

61. Birsen, E.B. Use of Hydrogen Fuel in Internal Combustion Engines. Master's Thesis, Natural Sciences Institute, Erciyes University, Kayseri, Turkey, 2008.

62. Akal, D.; Öztuna, S.; Büyükakın, M.K. A review of hydrogen usage in internal combustion engines (gasoline-Lpg-diesel) from combustion performance aspect. Int. J. Hydrogen Energy 2020, 45, 35257-35268. [CrossRef]

63. Overend, E. Hydrogen Combustion Engines. Master's Thesis, The University of Edinburgh, Scotland, UK, 1999.

64. Gadallah, H.A.; Elshenawy, A.E.; Elzahaby, M.A.; El-Salmawy, A.H.; Bawady, H.A. Effect of direct water injection on performance and emissions of a hydrogen fuelled direct injection engine. In Proceedings of the Ecologic Vehicles and Renewable Energies Monaco 2009, Monaco, France, 26-29 March 2009; pp. 178-191.

65. Shudo, T.; Omori, K.; Hiyama, O. $\mathrm{NO}_{x}$ reduction and $\mathrm{NO}_{2}$ emission characteristics in rich-lean combustion of hydrogen. Int. J. Hydrogen Energy 2008, 33, 4689-4693. [CrossRef]

66. Kose, H. Experimental Investigation of the Effect of Hydrogen Addition in Dual Fuel Mode on Engine Performance and Emission. Master's Thesis, Natural Sciences Institute, Selçuk University, Konya, Turkey, 2012.

67. Saravanan, N.; Nagarajan, G. Performance and emission studies on port injection of hydrogen with varied flow rates with Diesel as an ignition source. Appl. Energy 2010, 87, 2218-2229. [CrossRef]

68. Chitragar, P.R.; Shivaprasad, K.V.; Kumar, G.N. Use of Hydrogen in Internal Combustion Engines: A Comprehensive Study. J. Mech. Eng. Biomech. 2016, 1, 84-96.

69. Das, M.L. Hydrogen engine: Research and development (R\&D) programmers in Indian Institute of Technology (IIT), Delhi. Int. J. Hydrogen Energy 2002, 27, 953-965.

70. Ciniviz, M.; Hüseyin, K. Hydrogen use in internal combustion engine: A review. Int. J. Automot. Eng. Technol. 2012, 1, 1-15. 
71. Elsemary, I.M.M.; Attia, A.A.A.; Elnagar, K.H.; Elaraqy, A.A.M. Experimental investigation on performance of single cylinder spark ignition engine fueled with hydrogen-gasoline mixture. Appl. Therm. Eng. 2016, 106, 850-854. [CrossRef]

72. Sohret, Y.; Gurbuz, H.; Akcay, I.H. Energy and exergy analyses of a hydrogen fueled SI engine: Effect of ignition timing and compression ratio. Energy 2019, 175, 410-422. [CrossRef]

73. Wang, S.; Ji, C.; Zhang, B.; Liu, X. Lean burn performance of a hydrogen-blended gasoline engine at the wide open throttle condition. Appl. Energy 2014, 136, 43-50. [CrossRef]

74. Yu, X.; Li, G.; Du, Y.; Guo, Z.; Shang, Z.; He, F.; Shen, Q.; Li, D.; Li, Y. A comparative study on effects of homogeneous or stratified hydrogen on combustion and emissions of a gasoline/hydrogen SI engine. Int. J. Hydrogen Energy 2019, 44, 25974-25984. [CrossRef]

75. Acikgoz, B.; Celik, C. An experimental study on performance and emission characteristics of a methane-hydrogen fuelled gasoline engine. Int. J. Hydrogen Energy 2012, 37, 18492-18497. [CrossRef]

76. Gong, C.; Li, Z.; Yi, L.; Liu, F. Comparative study on combustion and emissions between methanol port-injection engine and methanol direct-injection engine with $\mathrm{H}_{2}$-enriched portinjection under lean-burn conditions. Energy Convers. Manag. 2019, 200, 112096. [CrossRef]

77. Kak, A.; Kumar, N.; Singh, B.; Singh, S.; Gupta, D. Comparative study of emissions and performance of hydrogen boosted SI engine powered by gasoline methanol blend and gasoline ethanol blend. SAE Technol. Pap. 2015, 10, 1677-1776.

78. Karagöz, Y.; Sandalcı, T.; Yüksek, L.; Dalkılıç, A.S.; Wongwises, S. Effect of hydrogen-diesel dual-fuel usage on performance, emissions and diesel combustion in diesel engines. Adv. Mech. Eng. 2016, 8, 1-13. [CrossRef]

79. Nuthan Prasad, B.S.; Pandey, J.K.; Kumar, G.N. Effect of hydrogen enrichment on performance, combustion, and emission of a methanol fueled SI engine. Int. J. Hydrogen Energy 2021, 46, 25294-25307. [CrossRef]

80. Yamin, J.A.; Hamdan, M.A. The performance of hydrogen-powered 4-stroke SI engine using locally designed fuel regulator. J. Braz. Soc. Mech. Sci. Eng. 2010, 32, 195-199. [CrossRef]

81. Christodoulou, F.; Megaritis, A. Experimental investigation of the effects of simultaneous hydrogen and nitrogen addition on the emissions and combustion of a diesel engine. Int. J. Hydrogen Energy 2014, 39, 2692-2702. [CrossRef]

82. Pan, H.; Pournazeri, S.; Princevac, M.; Miller, J.W.; Mahalingam, S.; Khan, M.Y.; Jayaram, V.; Welch, A.W. Effect of hydrogen addition on criteria and greenhouse gas emissions for a marine diesel engine. Int. J. Hydrogen Energy 2014, 39, 11336-11345. [CrossRef]

83. Salvi, B.L.; Subramanian, K.A. Experimental investigation on effects of compression ratio and exhaust gas recirculation on backfire, performance and emission characteristics in a hydrogen fuelled spark ignition engine. Int. J. Hydrogen Energy 2016, 41, 5842-5855. [CrossRef]

84. Vorst, W.; Finegold, J.G. Automotive hydrogen engines, and Onboard storage Methods. In Hydrogen Energy Fundamentals; Sun-Sentinel: Miami Beach, FL, USA, 1975.

85. Koten, H. Hydrogen effects on the diesel engine performance and emissions. Int. J. Hydrogen Energy 2018, 43, 10511-10519. [CrossRef]

86. Masood, M.; Ishrat, M.M.; Reddy, A.S. Computational combustion and emission analysis of hydrogen-diesel blends with experimental verification. Int. J. Hydrogen Energy 2007, 32, 2539-2547. [CrossRef]

87. Chen, B.; Zhang, L.; Han, J.; Chen, X. Investigating the effect of increasing specific heat and the influence of charge cooling of water injection in a TGDI engine. Appl. Therm. Eng. 2019, 149, 1105-1113. [CrossRef]

88. Elsemary, I.M.; Attia, A.A.; Elnagar, K.H.; Elsaleh, M.S. Spark timing effect on performance of gasoline engine fueled with mixture of hydrogen gasoline. Int. J. Hydrogen Energy 2017, 42, 30813-30820. [CrossRef]

89. Wang, J.; Duan, X.; Liu, Y.; Wang, W.; Liu, J.; Lai, M.-C. Numerical investigation of water injection quantity and water injection timing on the thermodynamics, combustion and emissions in a hydrogen enriched lean burn natural gas SI engine. Int. J. Hydrogen Energy 2020, 45, 17935-17952. [CrossRef]

90. Xu, P.; Ji, C.; Wang, S.; Cong, X.; Ma, Z.; Tang, C. Effects of direct water injection on engine performance in engine fueled with hydrogen at varied excess air ratios and spark timing. Fuel 2020, 269, 117209. [CrossRef]

91. Li, A.; Zheng, Z.; Peng, T. Effect of water injection on the knock, combustion, and emissions of a direct injection gasoline engine. Fuel 2020, 268, 117376. [CrossRef]

92. Vinod, S.Y.; Soni, S.L.; Sharma, D. Performance and emission studies of direct injection C.I. engine in duel fuel mode (hydrogendiesel) with EGR. Int. J. Hydrogen Energy 2012, 36, 3807-3817.

93. Akar, M.A.; Kekilli, E.; Bas, O.; Yildizhan, S.; Serin, H.; Ozcanli, M. Hydrogen enriched waste oil biodiesel usage in compression ignition engine. Int. J. Hydrogen Energy 2018, 43, 18046-18052. [CrossRef]

94. Rocha, H.M.Z.; Pereira, R.S.; Nogueira, M.F.M.; Belchior, C.R.P.; Tostes, M.E.L. Experimental investigation of hydrogen addition in the intake air of compressed ignition engines running on biodiesel blend. Int. J. Hydrogen Energy 2017, 42, 4530-4539. [CrossRef]

95. Deheri, C.; Acharya, S.K.; Thatoi, D.N.; Mohanty, A.P. A review on performance of biogas and hydrogen on diesel engine in dual fuel mode. Fuel 2020, 260, 116337. [CrossRef]

96. Salek, F.; Babaie, M.; Hosseini, S.V.; Anwar Bég, O. Multi-objective optimization of the engine performance and emissions for a hydrogen/gasoline dual-fuel engine equipped with the port water injection system. Int. J. Hydrogen Energy 2021, 46, 10535-10547. [CrossRef] 
97. Bari, S.; Esmaeil, M.M. Effect of $\mathrm{H}_{2} / \mathrm{O}_{2}$ addition in increasing the thermal efficiency of a diesel engine. Fuel 2010, 89, 378-383. [CrossRef]

98. Jamrozik, A.; Grab-Rogaliński, K.; Tutak, W. Hydrogen effects on combustion stability, performance and emission of diesel engine. Int. J. Hydrogen Energy 2020, 45, 19936-19947. [CrossRef]

99. Ghazal, O.H. Performance and combustion characteristic of CI engine fueled with hydrogen enriched diesel. Int. J. Hydrogen Energy 2013, 38, 15469-15476. [CrossRef]

100. Yilmaz, I.; Tastan, M. Investigation of hydrogen addition to methanol-gasoline blends in an SI engine. Int. J. Hydrogen Energy 2018, 43, 20252-20261. [CrossRef]

101. Lanz, A.; Heffel, J.; Messer, C. Hydrogen Fuel Cell Engines and Related Technologies; Energy Technology Training Center, College of the Desert: Palm Desert, CA, USA, 2001.

102. Shivaprasad, K.V.; Chitragar, P.R.; Kumar, G.N. Effect of Hydrogen Addition on Combustion and Emission Characteristics of High Speed Spark Ignition Engine-An Experimental Study. SAE Technol. Pap. 2015, 14, 1684-1693.

103. Shirk Matthew, G.; McGuire Thomas, P.; Neal Gary, L.; Haworth Daniel, C. Investigation of a $\mathrm{H}_{2}$-assisted combustion system for a light-duty diesel vehicle. Int. J. Hydrogen Energy 2008, 33, 7237-7244. [CrossRef]

104. Szwaja, S.; Grab-Rogalinski, K. Hydrogen combustion in a compression ignition diesel engine. Int. J. Hydrogen Energy 2009, 34, 4413-4421. [CrossRef] 